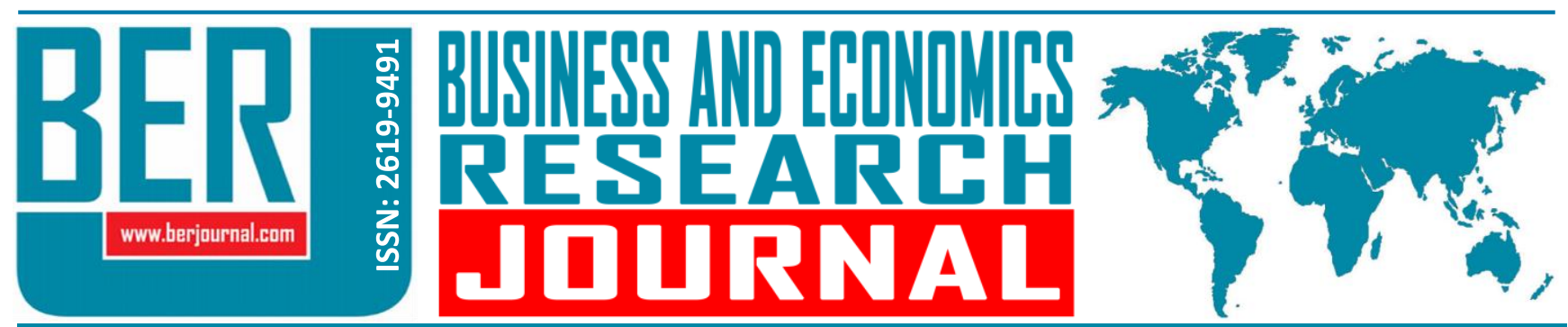

Business and Economics Research Journal Vol. 10, No. 4, 2019, pp. 903-913 doi: 10.20409/berj.2019.209

\title{
The Relationship between Personality Type and Perceived Stress Level: Evidence from Independent Public Accountants ${ }^{1}$
}

\begin{abstract}
Ali Ihsan Akguna, Nurhan Ture
Abstract: The role of stress in accounting profession has been examined in behavioral accounting literature in many studies conducted over the last three decades. The purpose of this study is to determine the relationship between personality and perceived stress level on the independent public accountants in Turkey by using Eysenck personality type used to identify the personality characteristics of the independent public accountants and the stress level scale to determine the sources of stress and to specify behavior types in stressful events. Our research findings establish that there is a significant difference between personality type and perceived stress level. In addition, there is a negative relationship between extraverted personality attribute and perceived stress level and a positive relationship between intraverted personality attribute and perceived stress level.
\end{abstract}

Keywords: Personality Types, Stress Level, Independent Public Accountants

JEL: M12, M41

Received : 11 March 2019

Revised : 15 May 2019

Accepted : 27 May 2019

Type : Research

\section{Introduction}

Stress which mostly stems from different factors and sense of the people has became a part of life but it affects each individual differently. Because everybody has different personality and the personality characteristics of the people are primary factor in increasing or decreasing of the stress. However, there is insufficient empirical evidence on the relationship between personality type and stress level of the accounting profession. This study researched the methods involved in the use of questionnaire to gather data based on personality types and perceived stress level independent accountants in Turkey.

Stress affects all people but each individual is affected from stress differently. Robins (1998) suggests that people have high level stress if there is an uncertainty and if the result of stressors is crucially important for them. Rogelberg et al. (2007) examine the impact of stress on organizational health and well-being and empirical evidence findings together and with employees be considered in a given cover to aid with euthanasia-related stress. Hussin (2008) states that stress develops when the number of potentially stressful events and also their importance level are very high for the people. Stranks (2005) argues that the less control, predictability and support, the more stress people live in their life. Shortly, it can be said that the degree of the stress is related with intensity of the stressful events and also importance, uncertainty, control level of these stressors. For example, perceived stress can affect health-related behaviors and physiological mechanisms. Hampel and Petermann (2006) find that perceived stress and coping is positively link with adjustment troubles. Luo and Roberts (2015)'s empirical findings suggest that increasing individuals'

a Assoc. Prof., PhD., Ankara Yıldırım Beyazıt University, Business School, Ankara, Turkiye, ihsan.akgun@ybu.edu.tr (ORCID ID: 0000002-6441-8196)

b Instructor, Private Sector in Kırıkkale, Turkiye, nurhan-ture@hotmail.com 
conscientiousness can lead to reduced stressful feelings. Similarly, Hamaideh et al. (2017) find that there is a significant difference in perceived stress among nursing students.

Personality often affects behavior differently in strategically different individuals' contexts. Thus, it is important to consider interactions between types of personality and features of the interpersonal context (Buss, 2009). Many studies have examined the importance of personality features in the stress process. For example, according to the Noser et al. (2014), personality has been shown to play an important role in the stress-linked negative effects. Their study results suggest that psychopathy moderated the relationship between stress and affective experiences were more reactive to stress level. Similarly, Miller et al. (2013) suggest that there is a strong negative emotions relationship between personality traits and pathological gambling. On the contrary, Murphy et al.'s (2014) findings suggest a significant positive relationship between personality traits and food addiction symptoms.

Personality consists of various measurements such as introverted and extraverted personality type (Akhavan et al., 2016). In this study, two proxies representing extravert and introvert personality type were built by using face-to-face meetings and dialogue. It is thought that stress which appears as a result of people's different sense and evaluation affects the extraverted people less than introverted ones. According to Jani (2014), extraverted people are positive, social and energetic while the introverted people have the opposite attributes, so extraverted people become happier and successful in stress management. The results of empirical evidence show that there are significant differences between personalities based on five factors. Akhavan et al.'s (2016)' findings suggest positive and significant affect associations between personality types and knowledge acquisition process.

The public and private sectors of globalized economy have been subjected to sustained change in recent years. In this economy, accountants are required to be equipped with technical skills and personal attributes to enable them to spearhead development, and thus, to lead revolution. Accounting associations across the globe are reacting to these stresses by ensuring that their qualification processes remain dynamic and relevant (Merino \& Aucock, 2017). The growing issue over the impact of stress on accounting profession, coupled with the popularity of the perceived stress scale as a generalized stress measure with other populations, motivated the current effort. Perceived stress among business people and practicing accountants as well as other profession can lead to negative results. More importantly, the accounting profession's distress over job-related and personal stress among its members can be traced back to the pioneering work, especially, during and after the peak tax season (Smith et al., 2014). Considerable progress has been made over the three decades toward the construction of a global stress paradigm among accountants in the workplace. Over this time period, a number of antecedents and consequences of individual and organizational stress have been identified and empirically verified (Fogarty et al., 2000; Smith, Derrick \& Koval, 2010).

Although some have previously examined the role of workplace deviance in personality type and stress level, overall accounting research in this context is relatively limited. This deficiency is surprising given the sole boundary-spanning nature of the accountant's profession. Unlike profession jobs with little client interaction, audit professionals spend a great deal of time on the frontlines, providing direct services for clients at client locations. Therefore, there exists empirical evidence to suggest that the concern over the potential carryover effects of excessive stress to the workplace has particular relevance to accounting majors (Jelinek \& Jelinek, 2008). Especially, public accounting has its share of highly stressed workers; it is among the most stressful professions (Fogarty et al., 2000; Jelinek \& Jelinek, 2008). The current study aims to further this investigation by examining the relationship between personality type and perceived stress level on the independent public accountants in Turkey.

Until now a lot of studies have been made about the relation between stress and personality of the people. For example, Otrar et al. (2002) investigated the impact of stress and coping on the psychological well-being of Turkish student and students from Turkic societies in Turkey. It was found that while men preferred using more problem-focused coping strategies, women showed more psychosomatic symptoms 
and although active coping strategies to deal with stress were found to be positively correlated with psychological well-being, passive coping strategies were negatively correlated with psychological wellbeing.

Sharma (2011) researched whether personality patterns determine an individual's ability to relax in his work environment. Results showed that extraverts relax easily than introverts and average and highintelligent participants used significantly more coping reactions than participants low in intelligence. Lucas et al. (2000) examined the relations between personality traits and subjective well-being. The results suggest the existence of a negative relationship between neurotic personality traits and subjective well-being, but a strongly positive relationship between being extraverted, responsibility, peacefulness and opennnes to experience and subjective well-being.

Prior empirical evidence suggests that public accounting is a high-stress profession (Collins \& Killough, 1992; Sanders, Fulks \& Knoblett, 1995; Jones et al., 2010). Stress may be even greater for accounting profession in today's economic environment. The profession has faced many difficult challenges such as an increasing liability risk, financial reporting standards overload, a lack of growth in the demand for services, and an explosion in technological advances to keep pace with. All of these factors can lead to a stressful time as well (Sanders, Fulks \& Knoblett, 1995). According to Weick (1983), accountants produce stress because they "place people in failure'. For success in accounting, being continuously critical of accounting data and its source is a fundamental necessity, while in terms of human relations the inability to accept human beings as damaged usually leads to severe personal problems, and hence stress. Furthermore, the positive association between career distresses and departure from public accounting suggests that a lack of opportunity for career development may prompt one's decision to leave the field (Collins \& Killough, 1992).

Additionally, prior empirical evidence examine attention to the potential effects of severe stress and stress in a wide set of professions, exploring both antecedents and outcomes of stress (Fogarty et al. 2000; Williams et al. 2001). For example, Jones et al.'s (2010) findings suggest that role stress, mediated by job stress and its effect on psychological well-being, has a negative impact on job products. The purpose of this research is to examine stress level of the independent accountants in Kırıkkale in terms of some demographic variables, the relation between perceived stress level and personality type and also specify the stress management techniques.

Yıldırım et al. (2004) findings suggest that there is a negative effect between stress level and stressor of the independent accountants. Yıldırım (2008) find that there is no difference between the stress level of accounting profession and accounting lecturers. Demir and Anasız (2008) find that intensive work, bureaucratic process and having more responsibility are the impact of factors that increase the stress level in accounting profession. Yanık (2017) suggest that it is difference the end the level of stress in the variables of age and experience years of accounting professors. Tekin et al. (2019) suggest that there is negative relationship between perceived stress and self-confident and optimistic methods; whereas have a positive relationship between perceived stress and helpless and subservient methods of the ways of coping with stress. In addition, although some studies about this subject exist, there are very limited number studies which examine the relation between personality type and stress level of the employees and the number of empirical studies is insufficient. Similarly, this research is important since it could potentially contribute to literature in which no research on independent accountants about this subject exists.

\section{Hypotheses Development, Data and Methodology}

\subsection{Hypotheses Development}

Stress that shows as a result of having different sense and comments of the people is felt at different levels by each person because people have very different personalities from each other. Güçlü (2001) suggest that some personality attributes cause stress but some other personality attributes may decrease stress. For that reason, it is thought that personality is a crucial factor within the tendency of people toward stress. Nia and Besharat (2010) and Karl, Peluchette and Herland (2007) findings suggest that the people who have 
extraverted personalities live with less stress compared with introverted people and also they are happier and more successful in their lives.

Mroczek and Almeida (2004) find that there is a strong relationship between stress and its negative effects. Koçyigit, Bal and Öztürk (2010) find that there is a significant relationship between demographic attributes and organizational stressors. In addition, Azizoğlu and Özyer (2010) find that adults felt burnout syndrome more than youths, single people felt more stress than married ones and also the workers with successful careers felt more stress than the other workers who are at the beginning of their careers. Yıldırım et al. (2004) and Zeytin and Gökgöz (2011) find low income as a stressor of the independent accountants. Thus, according to this information, our hypotheses were developed:

$\mathrm{H} 1$ : There is a significant relationship between personality types of the accountants' profession and perceived stress level.

$\mathrm{H} 2$ : There is a negative relationship between the extraverted personality attribute and the perceived stress level.

H3: There is a positive relationship between the introverted personality attribute and the perceived stress level.

\subsection{Data}

Participants were a community sample of 87 independent accountants in the Kırıkkale city located on the crossroads of major highways east of Ankara in Turkey. 22 female (25.3\%) and 65 male (74.7\%) independent accountants participated in the research. In terms of marital status, there are 73 married (83.9\%) and 14 single (16.1\%) employees (see appendix 1). Therefore, it may be said that most of the participants were married men. In this research there were two people $(2.3 \%)$ who were 30 years of age and below, 26 people (29.9\%) between the ages of 31-40, 35 people (40.2\%) between the ages of 41- 50, 17 people (19.5\%) between the ages of 51-60 and also 7 people (8.0\%) age 61 and over. As a result, it may be said that most of the participants were between the ages of 41-50. In this research when the independent accountants are examined in terms of gender and marital status most of them were married and men. So most of them consist from married men. When age variable is evaluated, it may be seen that most of the independent accountants were between 41-50 years of age and in terms of education level and most of them had post graduate degrees but there was no one with high school or doctorate degree. In addition, when the experience of them was examined, more than half of employees had at least eleven-year experience. So it may be said that most of them were experienced individuals. Also there were 37 people (42.5\%) who had an income between 3,000-4,999, 28 people (32.2\%) who had an income of 5,000 and above. For that reason, it is clear that more than half of the participants had an income of at least 3,000 and similarly more than half of the independent accountants have at least 50 taxpayers. Lastly, there are no Certified Public Accountants in this research; all are Independent Accountants and Financial Advisors and also 87 percent of these employees work independently in their jobs.

The data universe consisted of independent accountants that are registered to the Independent Accountants and Financial Advisors Trade Association in Kırıkkale. According to data from the association, there were 92 independent accountants that work actively. The sample of this research consisted of 87 independent accountants which were choosen randomly from the universe. It was assumed that this sample represented the universe that consists of 92 independent accountants. Then, face-to-face meetings were conducted with 87 independent accountants. In this study, perceived stress level Cronbach reliability coefficient is 0.80 , stress management success reliability coefficient is 0.74 and personality type reliability coefficient is 0.74 (Türe, 2017).

\subsection{Methodology}

Most of the personality psychologists agreed on the personality inventory, which was enlarged by Goldberg in 1990 (Goldberg, 1990). As a result of the literature research, some personality attributes were 
added to this questionnaire. This scale was used by Karaman et al. (2010). In addition, stress level questionnaire was prepared from Turnage \& Spielberger's (1991) job stress questionnaire.

The questionnaire instrument contains a set of questions describing the demographic characteristics of the independent accounts such as their income, age, gender, marital status and education level, which we tried to specify in Turkey. The items in questionnaire consisted of those developed by Goldberg (1990) and Turnage and Spielberger (1991), who formed 4 categories: demographic information, stres level, stress management success and personality type. Most of the personality psychologists compromised on the personality inventory, which was enlarged by Goldberg in 1990. As a result of the literature research, some personality attributes were added to this questionnaire. Stress level questionnaire was prepared from Turnage \& Spielberger's (1991) job stress questionnaire. A significant difference was found between personality type and perceived stress level of the independent accountants $F(1.85)=5.576, p=0.02<0.05$.). According to this model, personality type of the independent accountants explains twelve percent of the perceived stress level variance. Similarly, there was a relationship between income, vocational experience, age and perceived stress level but no relationship between gender, marital status and perceived stress level was observed.

Many previous studies have examined stress level in international arena, yet none of them attempted to investigate the extent of independent public accountants by registered profession. Personality types are characteristic human behaviours that seperate one from another and specify the tendency toward stressors. Because although some behavior increases people's stress levels other behaviours may cause high level stress on them. Factor analysis used by Eysenck identifies basic number of types that differs for each individual. Different from Cattel, whose research includes list of source traits, Eysenck's research includes few personality dimensions such as extraversion-introversion, neuroticism, and emotionally stable (Burger, 2006).

People under stress show some symptoms such as mental tension, anxiety, fatigue, changes in eating and sleeping habits (Ugoji, 2012). The main symptoms of stress range from physical to behavioral changes (Hariharan \& Rath, 2008). Different from individuals, the organisations are affected from stress negatively. As a result of excessive stress some problems are seen in organisations such as absenteeism, high fluctuation of staff, disciplinary problems, bullying, low productivity, accidents and increased costs from compensation or health care (Stranks, 2005; Mihaela, 2010). This study may create a resource for the larger works related to independent accountants and also help the other studies of this type in other sectors. Our study established that there is a significant difference between personality type and perceived stress level of the independent accountants. In our model, personality type of the independent accountants explains twelve percent of the perceived stress level variance. Similarly, there was a relationship between income, vocational experience, age and perceived stress level but no relationship between gender, marital status and perceived stress level was found.

\section{Empirical Findings}

Data were collected using a purposive sampling method from 87 independent public accountants using a self-reported questionnaire composed of perceived stress scale and personality type. The relationships between accounting professions' perceived stress level and personality type were determined using Pearson Correlation. In addition, factor analysis was conducted to ensure structure validity of the perceived stress level and obtain a functional dimensioning by determining the factor loads of the items in the scale. Kaiser Mayer Olkin (KMO) and Bartlett tests were used to test the conformity of the data to the factor analysis before doing the factor analysis. For the 87 test scale forms of 18 items that were evaluated, the KMO value was found to be 0.71 and the Bartlett test result was found to be $\chi 2=443.204(p \leq 0.05)$. Having a KMO value higher than 0.60 and a significant result of the Barlett test indicates that the data were suitable for the factor analysis (Foster et al., 2006). In this case, the KMO value that was found to be 0.71 is higher than the recommended KMO value. In this context, the scale data are suitable to carry out the factor analysis.

In our research, stres level Cronbach reliability coefficient was 0.80 , stress management success reliability coefficient was 0.74 and personality type reliability coefficient was 0.74 . According to the analysis 
results, it may be said that the scale is reliable. Croncbach's were above the cutoff point of 0.70 and the evidence of convergent and discriminant validity, the result illustrated that the measures were reliable (Elrehail, 2018). KMO and Bartlett tests were used to test the conformity of the data to the factor analysis before doing the factor analysis. For the 87 test scale forms of 13 items that were evaluated, the KMO value was found to be 0.77 and the Bartlett test result was found to be $\chi 2=366.042(p \leq 0.05)$. Having a KMO value higher than 0.60 and a significant result of the Barlett test indicate that the data were suitable for the factor analysis. After the repeated analysis, the KMO value for the 12 -item test scale form evaluated was found to be 0.77 and the Barlett test result was found to be $\chi 2=349.677$ ( $p \leq 0.05)$. In this case, the KMO value of 0.77 is higher than the recommended KMO value. In this context, the data in the scale are found to be suitable to conduct factor analysis.

Table 1. Correlation Analysis between Personality Types and Perceived Stress Level

\begin{tabular}{|l|l|c|c|}
\hline Component & & $\begin{array}{c}\text { Personality } \\
\text { Types }\end{array}$ & $\begin{array}{c}\text { Perceived } \\
\text { Stress Level }\end{array}$ \\
\hline Personality Types & Pearson Correlation & 1 & $0.348^{*}$ \\
\hline & Sig. (2-tailed) & & 0.020 \\
\hline Perceived Stress Level & Pearson Correlation & $0.348^{*}$ & 1 \\
\hline & Sig. (2-tailed) & 0.020 & \\
\hline
\end{tabular}

* Correlation is significant at the 0.05 level (2-tailed).

According to the results from Pearson Correlation analysis in Table 1, a positive and significant relationship was seen between personality types and the perceived stress level, $r=0.348, p=0.02<0.05$. As a result of this significant difference, simple regression analysis was made to specify the effects of personality types toward perceived stress level. Before implementing regression analysis, it was specified that there is a linear relationship between the perceived stress level and personality types and the data show normal distribution. As a result of being verified of the hypotheses, the data were analyzed and are shown in Table 2.

Table 2. Personality Types Simple Linear Regression Analyis

\begin{tabular}{|l|c|c|c|c|c|c|c|}
\hline Model & \multicolumn{7}{|c|}{ Predicted Variable: Perceived Stress Level } \\
\cline { 1 - 2 } Variables & B & ShB & $\boldsymbol{\beta}$ & $\mathbf{t}$ & $\mathbf{p}$ & $\begin{array}{c}\text { Pearson } \\
\text { Correlation }\end{array}$ & $\begin{array}{c}\text { Partial } \\
\text { Correlation }\end{array}$ \\
\cline { 1 - 2 } Constant & 4.215 & 0.540 & & 7.808 & 0.000 & 0.348 & 0.348 \\
\cline { 1 - 2 } $\begin{array}{l}\text { Personality } \\
\text { Type }\end{array}$ & 0.347 & 0.155 & 0.348 & 2.361 & 0.020 & & \\
\hline
\end{tabular}

As it is seen in Table 2, personality types of the independent accountants have a significant effect on the perceived stress level $(F(1-85)=5.576, p=0.02<0.05)$. According to this model, the personality type of independent accountants explains twelve percent of the perceived stress level variance $\left(R=0.338, R^{2}=0.121\right)$. In this study a significant difference was found between personality types and perceived stress level. These result are consistent with previous studies by Akhavan et al. (2016).

According to the results related to correlation analysis in Table 3, there is a negative and significant relationship between the extraverted personality type and the perceived stress level, $r=-0.391, p<0.05$. This relationship is medium-level between two variables. Therefore, if the extraverted personality type increases, the perceived stress level decreases. When the determination coefficient $\left(r^{2}=0.15\right)$ is taken into consideration, the extraverted personality type explains fifteen percent of the perceived stress level variance. 
Table 3. Correlation Analysis between Extraverted Personality Type and Perceived Stress Level

\begin{tabular}{|c|c|c|c|}
\hline Component & & $\begin{array}{c}\text { Perceived Stress } \\
\text { Level }\end{array}$ & $\begin{array}{c}\text { Extraverted } \\
\text { Personality Type }\end{array}$ \\
\hline Perceived Stress Level & Pearson Correlation & 1 & $-0.391^{*}$ \\
\hline & Sig. (2-tailed) & & 0.006 \\
\hline $\begin{array}{c}\text { Extraverted Personality } \\
\text { Type }\end{array}$ & Pearson Correlation & $-0.391^{* *}$ & 1 \\
\hline \multicolumn{2}{|c|}{0.006} & \\
\hline
\end{tabular}

* Correlation is significant at the 0.05 level (2-tailed) and ${ }^{* *}$ is significant at the 0.01 level.

According to the results about Pearson correlation analysis in Table 4, there is a positive and significant relationship between the introverted personality type and the perceived stress level, $r=0.591$, $\mathrm{p}<0.05$. This relationship is medium-level between two variables. Therefore, if the introverted personality type increases, the perceived stress level also increases. When the determination coefficient $\left(r^{2}=0.35\right)$ is taken into consideration, the introverted personality type explains thirty-five percent of the perceived stress level variance.

Table 4. Correlation Analysis between Introverted Personality Type and Perceived Stress Level

\begin{tabular}{|c|c|c|c|}
\hline Component & & $\begin{array}{c}\text { Perceived Stress } \\
\text { Level }\end{array}$ & $\begin{array}{c}\text { Introverted } \\
\text { Personality Type }\end{array}$ \\
\hline \multirow[t]{2}{*}{ Perceived Stress Level } & Pearson Correlation & 1 & $0.591^{*}$ \\
\hline & Sig. (2-tailed) & & 0.006 \\
\hline \multirow[t]{2}{*}{$\begin{array}{c}\text { Introverted Personality } \\
\text { Type }\end{array}$} & Pearson Correlation & $0.591^{* *}$ & 1 \\
\hline & Sig. (2-tailed) & 0.006 & \\
\hline
\end{tabular}

* Correlation is significant at the 0.05 level (2-tailed) and ** is significar

A negative relationship was found between the perceived stress level and the extraverted personality type, and also there is a positive relationship between the perceived stress level and the introverted personality type by consistent with previous studies by Ahadi \& Narimani (2010).

In this data, there is a negative and significant relationship between the income level and the perceived stress level, $r=-0.374, p<0.05$. When descriptive statistics of the accountants' vocational experiences are examined, the point average of the people who worked five years and under was $=2.93$, people who worked between six and ten years was $=3.13$, people who worked between eleven and fifteen years is $=3.03$, people who worked between sixteen and twenty years was $=2.94$ and lastly the people who work for twenty-one years and over was $=2.86$. It was found that there was a significant difference between the perceived stress level and vocational experience $(F(4-86)=0.336, p=0.04<0.05)$. The effect size related test result ( $\eta 2=0.06$ ) shows that this difference was medium level. As a result of the Tukey test, it was found that significant difference stems from the points of people who have experience between 11-15 years (3), 21 years and over (5), 6-10 years (2) and 16-20 years (4).

In this study, a significant relationship was found between vocational experience and the perceived stress level. According to the results on the correlation analysis in the data, there was a positive and significant relationship between age and perceived stress level, $r=0.429, p<0.05$. A positive and significant relationship was found between age and the perceived stress level. As a result of the independent-samples t-test it was specified that the average point of the men was $3.0169(\mathrm{~S}=0.73)$ and the average point of the women was $2.75(\mathrm{~S}=0.57)$, but no significant difference appeared between the average points $\mathrm{t}(85)=1.50$, $p=0.13>0.05)$. In other words, gender did not have a significant effect on the perceived stress level. 


\section{Conclusion}

The study provides to specify the relation between personality type and perceived stress level on the independent accountants. In this paper the stress level of the independent accountants has been examined in terms of some demographic variables, the relationship between stress level and personality types and how effectively they use the stress management techniques has been specified.

Our study results showed that personality type has a significant difference on the stress level of the independent accountants and also there was a relation between extraverted and intraverted personality type and perceived stress level and also stress management success. Only extraverted and intraverted personality type were examined in the data set of this study. Additionally, this study may be done in some special and public establishments so the awarenes of the participants may be increased and also more eye-opener results about stress and personality type may be reached. Our results are consistent with previous studies by Akhavan et al. (2016) and Lucas et al. (2000), who established a negative result relationship between personality traits and subjective well-being, but a positive relationship between extraverted and subjective well-being. Therefore, this study showed that extraverted people are more successful in stress management than introverted people. As a result of this study, a positive and significant relationship was found between the extraverted personality type and stress management success, but a negative relationship was found between the introverted personality type and stress management success. In addition, results similar to those in this study were found in the research of Sharma (2011).

The arithmetic mean of the perceived stress level states that the independent accountants feel stress both in their homes and also workplace because they do not spend enough time for private life, feel time pressure while working, mostly think that social support is insufficient and find that the work affects their health negatively. In addition, being married, most of the employees feel high stress in their workplace because of excessive work. For that reason, it is suggested that Chamber of Independent Accountants and Financial Advisors should activate fiscal holiday so they may spend more time with their family and also in social life. Similarly, some precautions against stress may be taken by the Chamber of Independent Accountants and Financial Advisors. With stress counseling, education programmes, seminers or conferences, the employees may think more positively and become more succesful in time management as well as stress management.

\section{Acknowledgements}

The autors are grateful for those people who took part in this survey reserach work.

\section{End Notes}

1. The previous version of this paper was partially presented as Graduate Thesis in Ankara Yıldırım Beyazıt University, Institute of Social Science, Management and Organisation Department by Nurhan Türe.

\section{References}

Ahadi, B., \& Narimani, M. (2010). Study of relationships between personality traits and education. Trakia Journal of Sciences, 8(3), 53-60.

Akhavan, P., Dehghani, M., Rajabpour, A., \& Pezeshkan, A. (2016). An investigation of the effect of extroverted and introverted personalities on knowledge acquisition techniques. Journal of Information and Knowledge Management Systems, 46(2), 194-206.

Azizoğlu, Ö., \& Özyer, K. (2010). Polislerde tükenmişlik sendromu üzerine bir ampirik çalışma. Anatolia Turizm Araştırmaları Dergisi, 21(1), 137-147.

Burger, J. M. (2006). Personality. USA: Thomson Higher Education. 
Buss, D. M. (2009). An evolutionary formulation of person-situation interactions. Journal of Research in Personality, 43, 241-242.

Collins, K. M., \& Killough, L. N. (1992). An empirical examination of stress in public accounting. Accounting, Organizations and Society, 17(6), 535-547.

Demir, M., \& Anasız, İ. (2008). Muhasebecilik mesleğinde mesleki stres kaynakları ve uygulanan bireysel stratejiler üzerine bir araştırma. Verimlilik Dergisi, 2008(3), 135-159.

Elrehail, H. (2018). The relationship among leadership, innovation and knowledge sharing: A guidance for analysis, Data in Brief, 19, 128-133.

Fogarty, T. J., Singh, J., Rhoads, G. K., \& Moore, R. (2000). Antecedents and consequences of burnout in accounting: Beyond the role stress model. Behavioral Research in Accounting, 12, 31-41.

Foster, J., Barkus, E., \& Yavorsky, C. (2006). Understanding and using advanced statistics. London: Sage Publications Inc.

Goldberg, L. R. (1990). An alternative description of personality, the big five factor structure. Journal of Personality and Social Psychology, 59(6), 1216-1229.

Güçlü, N. (2001). Stres yönetimi. Gazi Eğitim Fakültesi Dergisi, 21(1), 91-109.

Hamaideh, S. H., Al-Omari, H., \& Al-Modallal, H. (2017). Nursing students'perceived stress and coping behaviors in clinical training in Saudi Arabia. Journal of Mental Health, 26(3), 197-203.

Hampel, P., \& Petermann, F. (2006). Perceived stress, coping, and adjustment in adolescents. Journal of Adolescent Health, 38, 409-415.

Hariharan, M., \& Rath, R. (2008). Coping with life stress: The Indian experience. India: Sage Publications.

Hussin, WMA (2008). Managing stress at the workplace: The application of Wan Hussin 3-Dimensional Stress Management Model. Pranjana: Management Conscious Journal, 11(2), 16-26.

Jani, D. (2014). Relating travel personality to big five factors of personality. Turizam: znanstveno-stručni časopis, 62(4), 347-359.

Jelinek, R., \& Jelinek, K. (2008). Auditors gone wild: The "other" problem in public accounting. Business Horizons, 51(3), 223-33.

Jones, A., Norman, C. S., \& Wier, B. (2010). Healthy lifestyle as a coping mechanism for role stress in public accounting. Behavioral Research in Accounting, 22(1), 21-41.

Karaman, N. G., Dogan, T., \& Coban, A. E. (2010). A study to adapt the big five inventory to Turkish. Procedia-Social and Behavioral Sciences, 2(2), 2357-2359.

Karl, K. A., Peluchette, J. V., \& Harland, L. (2007). Is fun for everyone? Personality differences in healthcare providers's attitudes toward fun. Journal of Health and Human Services Administration, 409-447.

Koçyiğit, S. Ç., Bal, E. Ç., \& Öztürk, V. (2010). Muhasebe meslek mensuplarının örgütsel stres kaynaklarını belirlemeye yönelik bir araştırma: Ankara ili örneği. Eskişehir Osmangazi Üniversitesi Sosyal Bilimler Dergisi, 11(1).

Lucas, R. E., Diener, E., Grob, A., Suh, E. M., Shao, L. (2000). Cross-cultural evidence for the fundamental features of extroversion. Journal of Personality and Social Psychology, 79(3), 452-468.

Luo, J., \& Roberts, B. W. (2015). Concurrent and longitudinal relations among conscientiousness, stress, and selfperceived physical health. Journal of Research in Personality, 59, 93-103.

Merino, A., \& Aucock, M. (2017). Evaluation of an intervention aimed at developing the personal attributes of prospective entrants into the accounting profession. South African Journal of Accounting Research, 31(1), 1-18.

Mihaela, A. M. (2010). The concept of stress and ways of managing it. Revista Tinerilor Economisti (The Young Economists Journal), 1(14), 69-74.

Miller, J. D., MacKillop, J., Fortune, E. E., Maples, J., Lance, C.E., Campbell, W. K., \& Goodie, A. S. (2013). Personality correlates of pathological gambling derived from Big Three and Big Five personality models. Psychiatry Res. 206(1), 50-55.

Mroczek, D. K., \& Almeida, D. M. (2004). The effect of daily stress, personality and age on daily negative affect. Journal of Personality, 72(2), 355-378.

Murphy, C. M., Stojek, M. K., \& MacKillop, J. (2014). Interrelationships among impulsive personality traits, food addiction, and Body Mass Index. Appetite, 73, 45-50.

Nia, M. E., \& Besharat, M. A. (2010). Comparison of athletes' personality characteristics in individual and team sports. Procedia-Social and Behavioral Sciences, 5, 808-812. 
Noser, A. E., Zeigler-Hill, V. \& Besser, A. (2014). Stress and affective experiences: The importance of dark personality features. Journal of Research in Personality, 53, 158-164.

Otrar, M., Eksi, H., Dilmac, B., \& Sikin, A. (2002). The sources of stress, coping, and psychological well-being among Turkic and relative societies' students in Turkey. EDAM: Eğitim Danışmanlığı ve Araştırmaları Merkezi, 2, 473-506.

Robbins, S. P. (1996). Organizational behavior: Concept, controversies, applications (7th ed.). Englewood Cliffs, NJ: Prentice Hall.

Rogelberg, S. G., DiGiacomo, N., Reeve, C. L., Spitzmüller, C., Clark, O.L., Teeter, L., Walker, A. G., Carter, N. T., \& Starling, P. G. (2007). What shelters can do about euthanasia-related stress: An examination of recommendations from those on the front line. Journal of Applied Animal Welfare Science, 10(4), 331-347.

Sanders, J. C., Fulks, D. L., \& Knoblett, J. K. (1995). Stress and stress management in public accounting. The CPA Journal, 65(8), 46-49.

Sharma, H. K. (2011). Stress and relaxation in relation to personality. Sage Open, 1(2).

Smith, K. J., Derrick, P. L., \& Koval, M. R. (2010). Stress and its antecedents and consequences in accounting settings: An empirically derived theoretical model. Advances in Accounting Behavioral Research, 13, 113-42.

Smith, K. J., Rosenberg, D. L., \& Haight, G. T. (2014). An assessment of the psychometric properties of the perceived stress scale-10 (PSS10) with business and accounting students. Accounting Perspectives, 13(1), 29-59.

Stranks, J. (2005). Stress at work management and prevention. London: Elsevier Book Aid International.

Tekin, E., Çilesiz Yazgan, Z., \& Gede, S. (2019). Farklı mesleklerde çalışanların algılanan stres düzeyleri ve stresle başa çıkma tarzları üzerine bir araştırma. ODÜSOBIAD, 9(1), 79-89.

Türe, N. (2017). The relationship between stress level and personality and stress management techniques. Ankara Yıldırım Beyazıt University Social Science Institution Master Thesis, Ankara.

Turnage, J. J., \& Spielberger, C. D. (1991). Job stress in managers, professionals and clerical workers. Work \& Stress, 5(3), 165-176.

Ugoji, N. (2012). Perceived emotional intelligence and stress management among undergraduate students. IFE PsychologIA: An International Journal, 20(2), 102-106.

Weick, K. E. (1983). Stress in accounting systems. The Accounting Review, 58(2), 350-69.

Williams, E. S., Konrad, T. R., Scheckler, W. E., Pathman, D. E., Linzer, L., McMurray, J. E., Gerrity, M., Schwartz, M. (2001). Understanding physicians' intentions to withdraw from practice: The role of job satisfaction, job stress, mental and physical health. Health Care Management Review, 26(1), 7-19.

Yanık, A. (2017). Muhasebe meslek mensuplarının algıladıkları stres düzeyine yönelik bir araştırma. Uluslararası Ekonomik Araştırmalar Dergisi, 3(1), 99-107.

Yıldırım, O., Tektüfekçi, F., \& Çukacı, Y. C. (2004). Modern toplum hastalığı: Stres ve muhasebe meslek elemanı üzerindeki etkileri. Süleyman Demirel Üniversitesi Iktisadi ve Idari Bilimler Fakültesi Dergisi, 9(2), 1-20.

Yıldırım, S. (2008). Muhasebe öğretim elemanları ve meslek mensuplarının mesleki stres düzeyi üzerine bir araştırma. Muhasebe ve Finansman Dergisi, (38), 153-162.

Zeytin, M., \& Gökgöz, A. (2011). Muhasebe meslek mensuplarında strese neden olan faktörlerin incelenmesi: Yalova ve Bilecik illeri örneği. Sosyal Bilimler Elektronik Dergisi, 3, 99-118. 


\section{Appendix}

Appendix 1: The Distributions of Socio demographic Attributes Related Participants

\begin{tabular}{|c|c|c|}
\hline Variables & Frequency (n) & Percent Value (\%) \\
\hline \multicolumn{3}{|l|}{ Gender } \\
\hline Woman & 22 & 25.3 \\
\hline Man & 65 & 74.7 \\
\hline \multicolumn{3}{|l|}{ Marital Status } \\
\hline Married & 73 & 83.9 \\
\hline Single & 14 & 16.1 \\
\hline \multicolumn{3}{|l|}{ Age } \\
\hline 30 and under & 2 & 2.3 \\
\hline $31-40$ & 26 & 29.9 \\
\hline $41-50$ & 35 & 40.2 \\
\hline $51-60$ & 17 & 19.5 \\
\hline 61 and upper & 7 & 8.0 \\
\hline \multicolumn{3}{|l|}{ Education Level } \\
\hline Two-year degree & 11 & 12.6 \\
\hline Undergraduate & 72 & 82.8 \\
\hline Post Graduate & 4 & 4.6 \\
\hline \multicolumn{3}{|l|}{ Vocational Experience } \\
\hline 5 year and under & 3 & 3.4 \\
\hline 6-10 year & 9 & 10.3 \\
\hline 11-15 year & 20 & 23.0 \\
\hline 16-20 year & 20 & 23.0 \\
\hline 21 year and upper & 35 & 40.2 \\
\hline \multicolumn{3}{|l|}{ Average Income } \\
\hline $0-1299$ & 0 & 0 \\
\hline 1300-2999 & 22 & 25.3 \\
\hline $3000-4999$ & 37 & 42.5 \\
\hline 5000 and upper & 28 & 32.2 \\
\hline \multicolumn{3}{|l|}{ Position } \\
\hline \multicolumn{3}{|l|}{ Independent } \\
\hline Accountant and & 87 & 100 \\
\hline \multicolumn{3}{|l|}{ Financial Advisor } \\
\hline $\begin{array}{l}\text { Certified Public } \\
\text { Accountant }\end{array}$ & 0 & 0 \\
\hline \multicolumn{3}{|l|}{ The Way of Work } \\
\hline Free & 76 & 87.4 \\
\hline $\begin{array}{l}\text { Dependent to } \\
\text { Organisation }\end{array}$ & 9 & 10.3 \\
\hline $\begin{array}{l}\text { Common Accounting } \\
\text { Office }\end{array}$ & 2 & 2.3 \\
\hline \multicolumn{3}{|c|}{ The Number of Taxpayer } \\
\hline $0-50$ & 29 & 33.3 \\
\hline $51-100$ & 50 & 57.5 \\
\hline $101-150$ & 8 & 9.2 \\
\hline $151-200$ & 0 & 0 \\
\hline 201 and upper & 0 & 0 \\
\hline Total & 87 & 100.0 \\
\hline
\end{tabular}


This Page Intentionally Left Blank 